\title{
EPÍLOGO: FINANCIAMENTOS CONTINGENTES À RENDA TÊM FUTURO NO BRASIL?
}

Paulo Meyer Nascimento ${ }^{1}$

\section{INTRODUÇÃO}

Acesso gratuito ao ensino superior é frequentemente colocado como condição inegociável por quem valora educaçáo como direito e a percebe como meio de empoderamento das pessoas e de suas comunidades. Mesmo para quem enfatiza o ensino superior como investimento em capital humano, gratuidade no ponto de uso é condição necessária para que as portas da universidade estejam abertas a quem não teria condiçóes financeiras para pagar um curso superior. Excluir quem não pode pagar é restringir liberdades individuais e limitar o desenvolvimento humano² de um país.

Gratuidade irrestrita, contudo, também traz problemas. Mesmo incompleta, a transição para a gratuidade no Chile já exibe sinais de redução do investimento total nas instituiçóes de ensino superior (IES) e perspectiva de queda de qualidade e de atrofia da parcela do sistema tornada gratuita, o que tenderá a levar à exclusão dos mais pobres do ensino superior. ${ }^{3} \mathrm{Na}$ Argentina, o acesso irrestrito e gratuito a todos que possuam certificado de ensino médio impóe às universidades públicas matricular mais ingressantes do que sua capacidade instalada permite e, ao mesmo tempo, conviver com baixíssimas taxas de conclusão de curso. ${ }^{4} \mathrm{Na}$ Grécia, o não reconhecimento oficial de cursos pagos ${ }^{5}$ atrofia o sistema e obriga muitos gregos a buscar formaçáo superior em outros países.

No Brasil, a gratuidade irrestrita, aliada às dificuldades legais impostas à captação de recursos externos, mantém as universidades públicas em perene estado de precarização financeira, evidenciada com mais força sempre que crises fiscais reduzem as fontes de financiamento público. Isso restringe o crescimento das IES públicas e torna o ensino superior majoritariamente privado no país.

Problemas dessa ordem exigem soluçóes complexas que também envolvem discutir financiamento à pesquisa e à extensão, autonomia universitária e os riscos e oportunidades relacionados ao financiamento privado da educação. Náo obstante, parte da soluçáo passa pela forma como a gratuidade de acesso é garantida. Dito isto, gratuidade para o estudante náo implica, necessariamente, banir investimento privado e depender unicamente de recursos públicos. Os exemplos dados ajudam a ilustrar o quanto universalizar ensino superior com qualidade é particularmente difícil para países de renda média.

Significa, então, defender a cobrança generalizada de mensalidades, concedendo bolsas aqui e ali e disponibilizando empréstimos estudantis, como propôs o Banco Mundial ao governo brasileiro em 2017 ? Não. Empréstimos convencionais impulsionaram em todo o mundo o financiamento público a estudantes pós-secundários nas últimas sete décadas, mas seu esgotamento já é nítido em muitos países, inclusive no Brasil.

1. Técnico de planejamento e pesquisa na Diretoria de Estudos e Políticas Setoriais de Inovação e Infraestrutura (Diset) do Ipea.

2. Aqui entendido no sentido colocado por SEN, A. Desenvolvimento como liberdade. São Paulo: Companhia das Letras, 2000.

3. Como analisado em Lições da transição do Chile para a gratuidade no ensino superior, texto presente neste Radar.

4. FANELLI, A. G.; DEANE, C. A. Abandono de los estudios universitarios: dimensión, factores asociados y desafíos para la política pública. Revista Fuentes, n. 16, p. 85-106, fev. 2016.

5. A Constituição grega exige gratuidade em todos os estabelecimentos reconhecidos oficialmente, inclusive os privados. Cursos pagos não são, portanto, credenciados. Ver BROMME, T.; BRITTEN, B. Will Greece ever embrace private higher education? The Pie News, 3 fev. 2017. Disponível em: $<$ https://bit.ly/2PY6XQW>. Acesso em: 29 maio 2018.

6. BANCO MUNDIAL. Um ajuste justo: análise da eficiência e equidade do gasto público no Brasil. Brasília: The World Bank, 2017. 
O fim da gratuidade na Austrália (há três décadas) e na Inglaterra (há duas) tem mostrado ser possível compartilhar o financiamento dos estudos superiores entre o Estado e os egressos, isentando todos os estudantes de pagamentos durante os estudos ao mesmo tempo em que lhes garante que só contribuirão financeiramente com os custos do ensino se e na medida em que seus rendimentos futuros permitirem. Nos dois casos, viabilizou-se a expansão de vagas e de acesso. Esses países alcançaram isto por meio de amplos e bem-desenhados sistemas de empréstimos com amortizaçóes contingentes à renda futura (ECRs).

\section{QUE É IMPRESCINDÍVEL PARA UM ECR AJUDAR A FINANCIAR O ENSINO CONCILIANDO JUSTIÇA SOCIAL E SUSTENTABILIDADE FISCAL?}

Em Financiamento do ensino superior: questöes conceituais e a experiência internacional, neste Radar, Bruce Chapman e Dung Doan ressaltam duas vantagens-chave dos ECRs sobre empréstimos convencionais.

1) Suavização do consumo e seguro contra choques de renda: como o valor das prestaçôes limita-se a um percentual preestabelecido da renda e, normalmente, há uma faixa de isenção de pagamento, os ECRs não estrangulam financeiramente seus mutuários nem pesam no orçamento em momentos de dificuldade financeira.

2) Redução dos custos de transação e aumento de eficiência: a coleta dos pagamentos via retenção na fonte minimiza o risco de náo pagamento por ato deliberado do devedor e barateia a gestáo do programa.

Para que essas vantagens sejam efetivas, algumas condiçóes são imprescindíveis. A primeira, que os pagamentos sejam de fato limitados a um percentual da renda do devedor, sem exigências de cobranças mínimas nem suplementares e preferencialmente garantindo-lhe algum horizonte de perdão da dívida, ainda que somente em caso de morte. ${ }^{7}$ A segunda, que a coleta dos pagamentos efetivamente utilize os mecanismos mais eficientes de cobrança de tributos.

Prestações que não levam em conta a capacidade de pagamento do mutuário não devem ser parte de um ECR porque póem abaixo a sua característica de seguro contra choques de renda. ECR não é o mesmo que crédito consignado; seu objetivo é minimizar riscos tanto para quem empresta quanto para quem toma emprestado.

No financiamento estudantil, o caráter de seguro do ECR é particularmente importante, pois elimina justamente o risco de a dívida estudantil vir a comprometer o acesso do indivíduo a outros financiamentos. A possibilidade de ficar com o nome sujo pode afastar do ensino superior pessoas avessas ao risco, particularmente as mais pobres, para quem costumam ser maiores os custos de oportunidade envolvidos na decisão de estudar e também as incertezas acerca do próprio futuro e da qualidade dos cursos e das IES. Embora em um bom ECR inexista a figura da inadimplência e as sançóes dela decorrentes, a amortização pode vir a se estender por décadas, de forma que o náo pagamento tende a se concentrar em indivíduos que realmente deveriam ser subsidiados. Faz-se necessário, portanto, que a Procuradoria Geral da Fazenda Nacional (PGFN) perceba que, diferentemente dos empréstimos convencionais, nos ECR o eventual não pagamento é um subsídio implícito. Sua incorporação no desenho do programa focaliza melhor o auxílio governamental do que subsidiar taxas de juros, prática usual em instrumentos de financiamento público que é totalmente desnecessária em um ECR.

A característica de seguro do ECR permite cobrar taxas de juros no mínimo iguais às de títulos públicos de longo prazo emitidos pelo Tesouro Nacional. Taxas de juros em um ECR aumentam o tempo necessário para amortizar a dívida, mas não o valor das prestaçóes, sempre vinculadas à renda. Subsidiar taxas de juros, portanto, reduz receita do governo sem trazer benefícios adicionais aos mais pobres.

7. Assim é no ECR australiano. Já o ECR inglês perdoa dívidas porventura remanescentes após trinta anos do fim do período de estudos. 
Tudo isso ainda reforça a necessidade de otimizar a coleta dos pagamentos. A Receita Federal do Brasil (RFB) não deixa nada a dever a seus congêneres de países desenvolvidos e dispóe de avançados meios para aferição da renda e cobrança de tributos. É essencial, portanto, seu envolvimento direto na coleta dos pagamentos de um ECR no Brasil. Isso poderia demandar alguma modificação na legislação infraconstitucional, a fim de incluir como atribuição adicional da RFB a coleta de pagamentos de um ECR. Alternativamente, poder-se-ia optar por um modelo híbrido, instituindo-se um tributo cuja incidência cessasse uma vez transcorrido prazo e/ou atingido teto de contribuiçáo preestabelecidos. Assim facilitar-se-ia o envolvimento da RFB na coleta dos pagamentos e evitar-se-ia que alguns egressos pagassem muito mais do que o custo de sua formação.

Cuidado maior seria necessário na definição das fontes de renda sobre as quais incidisse a alíquota desse tributo ou desse ECR. Ideal que incida sobre todas as fontes de renda pessoal (salários, pró-labore, rendimentos de aplicaçóes, lucros, dividendos, heranças), a fim de maximizar arrecadação, particularmente entre os não assalariados. Dificuldades para fazer dessa forma podem ser políticas, mas não técnicas nem operacionais.

\section{OS "QUASE ECRs" NA HISTÓRIA DO BRASIL}

Já houve discussões sobre ECR no Brasil antes mesmo de sua adoção na Austrália. Em um texto para discussão do Ipea publicado em 1979, ${ }^{8}$ Alberto de Mello e Souza e Clóvis Faro propóem que as prestaçóes do Crédito Educativo (precursor do Fies) fossem contingentes à renda e que os egressos das universidades públicas passassem a pagar uma contribuição em moldes semelhantes. Todos os estudantes poderiam optar pelo ECR e sua amortização seria feita simultaneamente ao pagamento do imposto de renda. A recomendação de política, contudo, não foi adiante.

No âmbito do Sistema Financeiro de Habitação (SFH), buscou-se entre 1967 e 1988 proteger a capacidade de pagamento dos mutuários da casa própria equiparando a correção das prestaçóes à dos salários. Isso não foi um ECR, pois os pagamentos não eram baseados na remuneração do indivíduo, não envolviam desconto automático em folha e continuavam sendo exigidos mesmo em caso de desemprego. Implicava, ademais, subsídios que se mostraram insustentáveis quando, na década de 1980, os reajustes salariais descolaram-se totalmente da inflação, gerando um rombo de fato pago pelo Tesouro Nacional até hoje, como ressalta Manoel Pires em Alguns comentários a respeito das reformas recentes no Fies e os desafios atuais, neste Radar. Em 1993, criou-se o Plano de Comprometimento da Renda (PCR), que facultava ao mutuário solicitar revisáo do valor das prestaçôes sempre que ultrapassassem $30 \%$ da sua renda bruta. Não foi, contudo, capaz de reverter a crise do SFH, pois, além da burocracia envolvida nos processos de revisão das prestaçóes, os pagamentos não eram retidos na fonte e o risco de subdeclaração da renda era alto.

Voltando ao financiamento estudantil, duas propostas de emenda à Constituição (PEC) merecem destaque. Uma, já arquivada, ${ }^{9}$ propunha a criação de um fundo parcialmente financiado por uma contribuição social a ser paga por graduados e pós-graduados de IES públicas. Outra, ainda em tramitação, ${ }^{10}$ propóe retribuição individual dos egressos de IES públicas ou dos que tiveram seus estudos em IES privadas financiados pelo Estado. Um ECR ou um tributo do graduado caberia na regulamentação de ambas, se alguma dessas PECs houvesse sido aprovada.

8. Disponível em: <https://bit.ly/2CNLFSg>. Acesso em: 3 maio 2016. Posteriormente publicado como SOUZA, A. M.; FARO, C. Crédito educativo e ensino pago: sugestões para o financiamento do ensino universitário. Fórum Educacional, v. 4, n. 1, p. 3-17, 1980.

9. SCHONS, S. et al. Proposta de Emenda à Constituição (PEC) no 217, de 2003. Brasilia: Câmara dos Deputados, 2003. Disponível em: <https://bit.ly/2ERBChU>. Acesso em: 13 dez. 2015.

10. FIGUEIRÓ, R. et al. Proposta de Emenda à Constituição (PEC) no 34, de 2014. Brasília: Senado Federal, 2014. Disponível em: <https://bit.ly/2JrlUbW>. Acesso em: 13 dez. 2015. 


\section{AS REFORMAS RECENTES DO FIES TORNARAM-NO UM ECR?}

A Lei $n^{\circ}$ 13.530/2017 prevê pagamentos contingentes à renda no Fies, vinculando até $20 \%$ dos rendimentos brutos totais para pagamento do empréstimo estudantil. Regulamentaçóes posteriores limitam, por enquanto, a vinculação máxima a 13\% do salário e impóem a empregadores de mutuários do Fies coletarem esses pagamentos por meio do Sistema de Escrituração Digital das Obrigações Fiscais, Previdenciárias e Trabalhistas (eSocial). Estas e outras novidades discutidas em alguns dos textos desta edição buscam reduzir inadimplência e retomar a sustentabilidade fiscal do Fies.

Vale ressaltar, contudo, que se exige coparticipação de todos estudantes beneficiados e pagamento mínimo dos egressos que deverem ao Fies e a quem o eSocial não alcance. Falta também clareza se e como serão aplicadas regras de perdão por decurso de tempo. Tudo isto compromete o caráter de seguro. Ademais, por mais que o eSocial represente avanços, perde-se uma grande oportunidade de maximizar pagamentos ao náo envolver a RFB na coleta e assim alcançar outras fontes de renda além dos salários. Ressalte-se, também, que a política de juro real zero gera custos fiscais desnecessariamente elevados e que as regras do programa ainda são de difícil compreensão. O Fies caminha para um ECR, mas questóes cruciais de proteção da pessoa, otimização da coleta e simplificação das regras ainda precisam ser sanadas para que seus objetivos sejam de fato alcançados.

\section{CONSIDERAÇÕES FINAIS}

O Brasil dispóe de condiçóes para implementar um amplo e bem-desenhado sistema de ECR para financiar estudantes de ensino superior, independentemente se matriculados em IES privadas ou públicas. Trata-se de uma política com potencial de, a médio e longo prazos, universalizar a gratuidade durante os estudos, mérito dos melhores sistemas do mundo. Isto porque um bem-desenhado ECR viabilizaria recursos adicionais para IES públicas, dando-lhe condiçóes de expansão, e daria sustentabilidade ao financiamento público a quem estuda em IES privadas, buscando a efetiva consecução do direito à educação sem desperdiçar recursos públicos. Simulaçóes feitas a partir de um painel com dados da Pesquisa Nacional por Amostra de Domicílios Contínua (PNAD Contínua) sugerem que, sem subsídios desnecessários e com o envolvimento da RFB na coleta dos pagamentos, um ECR com alíquotas correspondentes à metade das do imposto de renda, porém incidindo sobre toda a renda pessoal bruta aferível, permitiria arrecadar até mais de $90 \%$ dos montantes emprestados. ${ }^{11}$

Ainda que os desafios legislativos e operacionais não sejam pequenos, as condições técnicas e institucionais existem. O principal entrave para a adoção de um sistema de ECR baseado nas melhores práticas internacionais seria eminentemente político.

\footnotetext{
11. Resultado dos cenários mais otimistas entre os que foram simulados. Em todos os cenários, os valores dos empréstimos variavam de $R \$ 5$ mil a $R \$ 300$ mil, tomando-se como dívida média o valor de $R \$ 50$ mil e assumindo-se desvio-padrão de 0,5. Mesmo nos cenários mais pessimistas, com juros altos e salários reais estáveis, o percentual de não pagamento foi sempre menor do que as taxas de inadimplência reportadas em $A$ reestruturação do Fies, neste Radar. Ver cenários completos em: NASCIMENTO, P. M. Modelling income contingent loans for higher education student financing in Brazil. 2018. Tese (Doutorado em Economia) - Universidade Federal da Bahia, Salvador, 2018.
} 